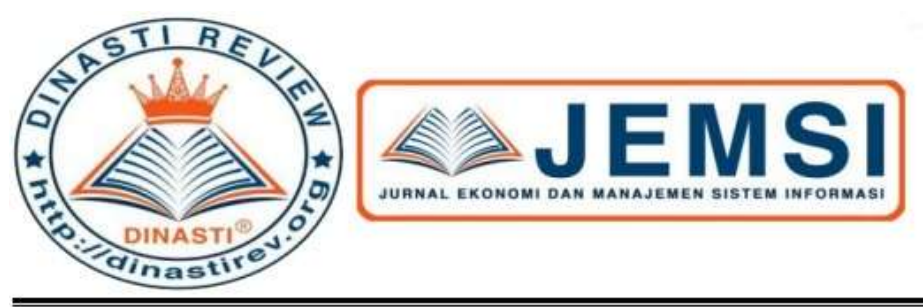

\title{
PENGARUH KINERJA KEUANGAN DAN GOOD CORPORATE GOVERNANCE TERHADAP NILAI PERUSAHAAN TAMBANG (Studi Kasus Bursa Efek Indonesia Dari Tahun 2015-2018)
}

\author{
Solagratia Siringoringo ${ }^{1}$, Jhon Rinaldo ${ }^{2}$ \\ 1) Universitas Mercubuana, Jakarta, Indonesia \\ 2) Universitas Ekasakti, Padang, Indonesia
}

ARTICLE INFORMATION

Received: 16 Desember 2019

Revised: 21 Desember 2019

Issued: 29 Desember 2019

(filled in by Editor)

Corresponding author: first author

E-mail:

solagratiasiringoringo@gmail.com

jhonrinaldo2010@gmail.com

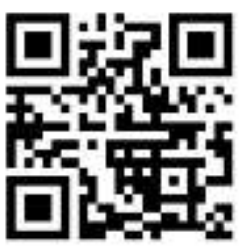

DOI:10.31933/JEMSI
Abstrak: Tujuan dari penelitian ini adalah untuk menganalisis kinerja keuangan yang diukur dengan Return on Assets (ROA) terhadap nilai perusahaan yang diukur dengan Tobin's Q serta untuk menganalisis Good Corporate Governance sebagai variabel moderasi.Obyek penelitian adalah perusahaan Tambang. Teknik yang digunakan untuk menganalisis pengaruh kinerja keuangan terhadap nilai perusahaan adalah analisis regresi linier berganda. Hasil penelitian menunjukkan kinerja keuangan berpengaruh terhadap nilai perusahaan, sedangkan Good Corporate Governance bukanlah variabel yang memoderasi hubungan kinerja keuangan dengan nilai perusahaan.

Kata Kunci: Kinerja Keuangan, Good Corporate Governance, Nilai Perusahaan.

\section{PENDAHULUAN}

Indonesia termasuk salah satu negara yang berkembang di dunia, hal ini terbukti dengan adanya pembangunan di segala bidang termasuk pembangunan sektor ekonomi. Perekonomian di Indonesia yang semakin membaik menyebabkan timbulnya gairah bagi para pengusaha untuk mengelola perusahaannya di Indonesia. Salah satu pengelolaan yang harus diperhatikan adalah masalah keuangan yang penting bagi kelangsungan hidup perusahaan, keuangan suatu perusahaan berkaitan dengan sumber dana dan penggunaannya. Semakin efisien penggunaan dan pengelolaan dana berarti semakin baik bagi perusahaan. Agar dana dalam perusahaan dapat dipenuhi secara cukup, maka dituntut adanya pengelolaan dan penentuan secara tepat terhadap sumber dana. Sumber dana dapat dipilih atau ditentukan apakah dari modalsendiri atau modal dari luar perusahaan dalam hal ini pemegang saham. Oleh karena itu untuk dapat memenuhi ekspektasi dari pemegang saham harus diwujudkan pula sebuah implementasi praktik tata kelola perusahaan atau Good Corporate Governance (GCG). Dengan pengawasan terhadap GCG yang diterapkan pada perusahaan diharapkan 
penerapan GCG tersebut diperbaiki dan ditingkatkan agar dapat meningkatkan kinerja perusahaan baik secara finansial maupun operasional (Otoritas Jasa Keuangan, 2014).

Penelitian ini menggunakan perusahaan tambang sebagai penelitian karena saham yang berasal berasal dari perusahan tambang merupakan saham yang paling sensitive dengan isu eksternal, seperti politik, bencana alam, dan lainnya. Selain itu ada pula isu internal karena kinerja perusahaan, perubahan struktur kepemimpinan dan lainnya.

Beberapa tahun terakhir banyak perusahaan semakin menyadari pentingnya menerapkan program Good Corporate Governance (GCG) sebagai bagian dari strategi bisnisnya. Hal tersebut merupakan suatu faktor yang dapat mempengaruhi nilai perusahaan. Masalah Corporate Governace muncul karena terjadinya pemisahan antara kepemilikan dan pengen-dalian perusahaan. Pemisahan ini didasarkan pada Teori Agensi (Agency Theory) yang dalam hal ini manajemen cenderung akan meningkatkan keuntung-an pribadinya daripada tujuan perusahaan. Oleh sebab itu, selain memiliki kinerja keuangan yang baik perusahaan juga diharapkan memiliki tata kelola (Corporate Governance) yang baik. Tata kelola perusahaan yang baik menggambarkan bagaimana usaha manajemen mengelola aset dan modalnya dengan baik agar menarik para investor. Pengelolaan aset dan modal suatu perusahaan dapat dilihat dari kinerja keuangan yang ada. Jika pengelolaannya dilakukan dengan baik maka, otomatis akan meningkatkan nilai perusahaan. Adapun tujuan peneliti-an ini adalah untuk mengetahui pengaruh kinerja keuangan terhadap nilai perusahaan dengan variabel pemoderasi Good Corporate Governance.

Nilai perusahaan adalah sangat penting karena tujuan yang ingin dicapai manajemen keuangan adalah memaksimisasi nilai perusahaan, jika perusahaan berjalan dengan baik, maka nilai perusahaan akan meningkat atau dapat dikatakan memaksimisasi harga saham. Banyak faktor yang mempengaruhi nilai per-usahaan, yang mana penelitian mengenai faktorfaktor yang berpengaruh terhadap nilai perusahaan sendiri telah banyak dilakukan, antara lain kinerja keuangan suatu perusahaan, kebijakan deviden, corporate governance dan lain sebagainya.

Penelitian ini memiliki variabel independen kinerja perusahaan dan GCG, variable dependen nilai perusahaan, berdasarkan replikasi atas penelitian (Pertiwi (2012). Hasil penelitian yang dilakukan oleh Pertiwi (2012) pada perusahaan sektor food and beverage pada tahun 2012 ini menunjukkan bahwa Kinerja keuangan yang diukur dengan ROA mampu meningkatkan nilai perusahaan food and beverages yang terdaftar di Bursa Efek Indonesia. Hal ini menunjukkan bahwa semakin tinggi kinerja keuangan, maka semakin baik nilai perusahaan tersebut. Terbukti bahwa jika penawaran tinggi maka akan meningkatkan permintaan. Hal ini selanjutnya akan meningkatkan daya tarik perusahaan kepada investor. Peningkatan daya tarik perusahaan menjadikan perusahaan tersebut makin diminati investor, karena tingkat keuntungan akan semakin besar. Good Corporate Governance tidak mampu memoderasi pengaruh kinerja keuangan terhadap nilai perusahaan food and beverages yang terdaftar di Bursa Efek Indonesia. Hal ini menunjukkan bahwa variabel Good Corporate Governance yang diproksikan dengan kepemilikan manajerial bukanlah variabel pemoderasi. Disebabkan oleh karena struktur kepemilikan manajerial di Indonesia masih sangat kecil dan didominasi oleh keluarga. Pemilik (principal/investor/ pemegang saham) belum bisa memberikan keper-cayaan penuh mengenai jalannya perusahaan kepada manajemen perusahaan. Di samping itu, pemegang saham menganggap bahwa Dewan Komisaris tidak memiliki pengetahuan yang cukup mengenai perusahaan mereka. 
Penerapan GCG yang baik didasarkan pada asas kewajaran, transparasi, akuntabilitas, tanggung jawab, dan kemandirian atau independensi (Kaihatu, 2006; Gingerich \& Hadiputranto, 2002). Penerapan GCG juga dilakukan untuk meningkatkan nilai shareholder, dan memastikan manajer melakukan kinerjanya untuk meningkatkan return bagi pemegang saham. Selain itu juga, diharapkan bahwa penerapan GCG berdampak baik pada kinerja perusahaan. Meskipun, sampai sekarang ini penerapan GCG masih menjadi tantangan bagi perusahaan untuk dapat menerapkannya (Kaihatu, 2006; Yi Lin, 2010). Penerapan GCG yang dilakukan dengan efektif dapat meningkatkan efisiensi dan pertumbuhan ekonomi sekaligus kepercayaan investor (OECD, 2004). Peningkatan penerapan GCG menjadi kebutuhan yang mendasar sebab investasi akan mengikuti sektor yang mengadopsi standar tata kelola efisien (OECD, 2004). Perusahan yang menerapkan GCG seharusnya memiliki kinerja perusahaan yang baik.

Penelitian yang dilakukan Midiastuti et al. (2003) di Indonesia kepemilikan manajerial mampu menjadi mekanisme Good Corporate Governance yang mampu mengurangi masalah ketidak selarasan kepentingan antara manajer dengan pemilik atau pemegang saham atau dapat dikatakan semakin meningkat proporsi kepemilikan saham manajerial maka semakin baik kinerja perusahaan.

\section{KAJIAN PUSTAKA}

\section{Agency Theory}

Menurut Jensen \& Meckling (1976) teori agensi adalah hubungan antara pemegang saham sebagai principal dengan manajemen sebagai agent dimana principal adalah pihak yang mempekerjakan agent untuk melakukan tugas bagi kepentingan principal, sedangkan agent adalah pihak yang menjalankan kepentingan principal sesuai dengan wewenang yang telah diberikan. Konflik keagenan dapat muncul akibat adanya perbedaan kepentingan (confilct of interest) antara principal dan agent (Hill \& Jones, 1992). Hal ini disebabkan karena masing-masing pihak ingin memaksimalkan kepentingan pribadi atas biaya pihak lain, sehingga perusahaan harus mengeluarkan agency cost untuk meminimalkan agency problem (Jensen \& Meckling, 1976). Terdapat 2 tipe konflik keagenan, yaitu tipe I yang merupakan konflik antara pemegang saham dan manajemen dan konflik keagenan tipe II yang melibatkan investor mayoritas dan investor minoritas (Villalonga \& Amit, 2006).

\section{Nilai Perusahaan}

Tujuan pokok yang ingin dicapai perusahaan adalah memaksimumkan nilai perusahaan. Tujuan tersebut dipergunakan karena dengan memaksimum-kan nilai perusahaan maka pemilik perusahaan akan menjadi lebih makmur atau menjadi semakin kaya (Husnan, 2000). Nilai perusahaan sangat penting karena dengan nilai perusahaan yang tinggi akan diikuti oleh tingginya kemakmuran pemegang saham (Brigham \& Gapenski, 1996). Semakin tinggi harga saham maka semakin tinggi pula nilai perusahaan. Nilai perusahaan yang tinggi menjadi keinginan para pemilik perusahaan, sebab dengan nilai yang tinggi menunjukan kemakmuran pemegang saham juga tinggi. Kekayaan pemegang saham dan perusahaan dipresentasikan oleh harga pasar dari saham yang merupakan cerminan dari keputusan investasi, pendanaan (financing), dan manajemen aset. 


\section{Good Corporate Governance}

Menurut Dinar (2017), GCG adalah salah satu pilar dari sistem ekonomi pasar berkaitan erat dengan kepercayaan baik terhadap perusahaan yang melaksanakannya maupun terhadap iklim usaha di suatu negara. Penerapan GCG mendorong terciptanya persaingan yang sehat dan iklim usaha yang kondusif. Berikut ini akan dijelaskan mekanisme Good Corporate Governance yang berhubungan dengan variabel penelitian yang diantaranya:

1. Kepemilikan manajerial

Kepemilikan saham manajemen adalah kepemilikan saham perusahaan yang dimiliki oleh manajemen baik direksi, komisaris maupun karyawan dengan persyaratan tertentu untuk memiliki saham tersebut. Kepemilikan saham oleh manajemen aka mengurangi agency problem diantara manajer dan pemegang saham yang dapat dicapai melalui penyelarasan kepentingan diantara pihak-pihak yang berbenturan kepentingan.

Kepemilikan manajerial bisa diukur dari jumlah presentase saham yang dimiliki manajemen. Kepemilikan manajerial cukup kuat dalam melaksanakan Good Corporate Governance, karena berperan penting dalam penerapan GCG dengan prinsip-prinsip yang sudah ada. Kepemilikan manajerial pada suatu perusahaan dapat diukur dengan rumus:

\section{Kepemilikan Manajerial $=\frac{\text { Kepemilikan saham manajerial }}{\text { Total saham yang beredar }}$}

2. Kepemilikan Institusional

Kepemilikan institusional memiliki peranan yang penting dalam meminimalisasi konflik keagenan yang terjadi diantara pemegang saham dengan manajer. Keberadaaan investor institusional dianggap mampu mengoptimalkan pengawasan kinerja manajemen dengan memonitoring setiap keputusan yang diambil oleh pihak manajemen selaku pengelola perusahaan.

Kepemilikan institusional ditunjukkan dengan tingginya persentase saham perusahaan yang dimiliki oleh pihak institusi. Kepemilikan institusional diukur dengan membagi jumlah saham yang dimiliki oleh institusi dengan jumlah saham yang beredar. Berikut rumus untuk menghitung kepemikan institusional.

$$
\text { Kepemilikan Institusional }=\frac{\text { Kepemilikan saham institusional }}{\text { Total saham yang beredar }}
$$

3. Komisaris independen

Komisaris Independen adalah anggota Dewan Komisaris yang tidak memiliki hubungan keuangan, kepengurusan, kepemilikan saham dan/atau hubungan keluarga dengan anggota Dewan Komisaris lainnya, Direksi dan/atau Pemegang Saham pengendali atau hubungan lain yang dapat mempengaruhi kemampuannya untuk bertindak independen.

Komisaris Independen diukur berdasarkan persentase jumlah Komisaris Independen terhadap jumlah total Komisaris yang ada dalam susunan Dewan Komisaris perusahaan.

$$
\text { Kepemilikan Independen }=\frac{\text { Jumlah Komisaris Independen }}{\text { Jumlah Dewan Komisaris }}
$$




\section{Kinerja Perusahaan}

Kinerja perusahaan adalah gambaran mengenai hasil atau prestasi perusahaan selama periode waktu tertentu, yang dipengaruhi oleh kegiatan operasional perusahaan dengan memanfaatkan sumber daya yang dimiliki dalam upaya untuk mewujudkan sasaran, tujuan, misi, dan visi perusahaan yang telah ditetapkan sebelumnya (Bastian, 2001). Kinerja Perusahaan dapat dilakukan dengan analisa laporan keuangan, Menurut Mulyadi (2001:416), "Kinerja merupakan penilaian perilaku manusia dalam suatu organisasi ntuk tercapainya tingkat prestasi atau hasil nyata yang positif. "Kinerja keuangan adalah prestasi dibidang keuangan yang unsur-unsurnya berkaitan dengan pendapatan, pengeluaran, keadaan operasional secara keseluruhan, struktur utang dan hasil investasi. Penilaian kinerja keuangan berbeda dengan penilaian barang baik berwujud maupun tidak berwujud. Untuk melakukan analisis penilaian aset, cukup diperiksa obyek aset secara fisik, kondisi ekonomi, dan fungsionalnya yang bersifat statis. Penilaian kinerja keuangan perusahaan dilakukan terutama untuk beberapa tujuan sehubungan dengan kegiatan seperti pengambil alihan perusahaan, pemberian kredit, perluasan usaha dan sebagainya. Hasil atau prestasi kerja perusahaan digunakan untuk memberikan gambaran kepada pihak yang membutuhkan seperti pemegang saham dan stakeholders mengenai efektifitas manajemen dalam memperoleh keuntungan atas pengelolaan aset, ekuitas maupun hutang perusahaan (Astuti et al., 2015). Pengukuran kinerja perusahaan yang digunakan dalam penelitian ini adalah ROA. ROA menggambarkan kemampuan perusahaan dalam mengelolah aset untuk menghasilkan laba (Shinduja, 2009).

\section{Kinerja Perusahaan yang Diukur dengan Return on Asset (ROA)}

Kinerja perusahaan dapat diukur dengan menggunakan rasio keuangan (Prasinta, 2012). Investor melakukan penanaman modal salah satunya dengan melihat rasio profitabilitas (Prasinta, 2012). Rasio profitabilitas yang digunakan dalam penelitian ini menggunakan Return on Asset (ROA) karena dapat memberikan gambaran tingkat pengembalian keuntungan yang dapat diperoleh investor atas investasinya (Prasinta, 2012). Selain itu dengan ROA, investor dapat melihat bagaimana perusahaan mengoptimalkan penggunaan asetnya untuk dapat memaksimalkan laba yang juga menjadi tujuan GCG untuk menggunakan aset dengan efisien dan optimal (OECD, 2004). ROA merupakan rasio yang digunakan untuk mengukur kemampuan manajemen perusahaan dalam memperoleh keuntungan dengan memanfaatkan keseluruhan total aset yang dimiliki (Attar, Islahuddin, \& Shabri, 2014). ROA mengukur seberapa efektif perusahaan dapat mengubah pendapatan dari pengembalian investasinya menjadi asset. Semakin tinggi ROA perusahaan, semakin baik. Beberapa perusahaan menekankan net margin yang tinggi untuk meningkatkan ROA mereka. Untuk menghitung ROA menggunakan rumus (Permata, Kusumawati, \& Suryawati, 2012):

\section{Kerangka Konseptual}

$$
R O A=\frac{\text { Net Income atau Earning After Tax }}{\text { Total Asset }}
$$

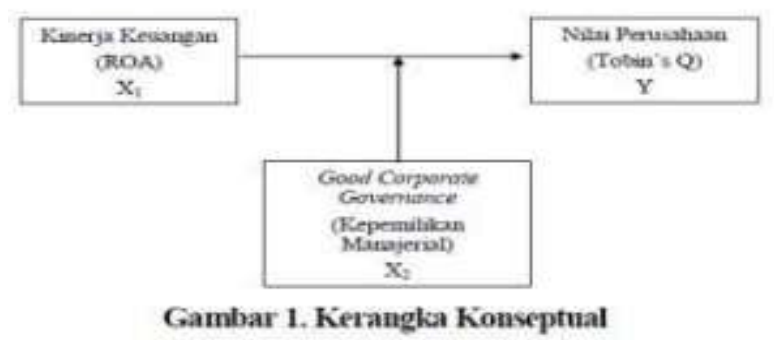


Sesuai dengan kerangka konseptual di atas maka penelitian ini akan menguji hipotesis yang pertama, diduga bahwa Kinerja keuangan mempunyai pengaruh positif terhadap nilai perusahaan tambang yang terdaftar di Bursa Efek Indonesia. Kedua menguji hipotesis diduga bahwa Good Corporate Governance mampu memoderasi pengaruh kinerja keuangan terhadap nilai perusahaan tambang yang terdaftar di Bursa Efek Indonesia.

\section{METODE PENELITIAN}

Variabel dependen dalam penelitian ini adalah nilai perusahaan. Pengukuran nilai perusahaan meng-gunakan Tobin's Q yang dikembangkan Klapper dan Love (dalam Hidayah, 2008). Tobin's Q dihitung dengan rumus, sebagai berikut:

$$
\begin{aligned}
& Q=\frac{((C P \times \text { Jumlah saham beredar })+(T L+1))-C A}{T A} \\
& \text { Keterangan: } \\
& \mathrm{Q}=\text { Nilai Perusahaan } \\
& \mathrm{CP}=\text { Closing Price } \\
& \mathrm{TL}=\text { Total Liabilities } \\
& \mathrm{I}=\text { Irventory } \\
& \mathrm{CA}=\text { Current Assets } \\
& \mathrm{TA}=\text { Total Assets }
\end{aligned}
$$

Variabel Independen yaitu kinerja keuangan diukur dengan Return on Assets (ROA). Indikator ini digunakan untuk mengukur kemampuan total aktiva dalam menghasilkan keuntungan.

Variabel Pemoderasi, adalah variabel yang mempengaruhi (baik memperlemah atau memper-kuat) hubungan (agency effect) antara variabel independen ke variabel dependen.

Variabel Pemo-derasi dalam penelitian ini adalah Good Corporate Governance yang diproksikan dengan kepemilikan manajerial. Teknik penentuan sampel yang digunakan dalam penelitian ini adalah purposive sampling, yang berarti pemilihan sampel berdasarkan kriteria tertentu.

Terdapat 41 perusahaan makanan dan minuman yang memenuhi kriteria pengambilan sampel pada tahun 2015 hingga 2018. Berdasarkan metode purposive sampling dan kriteriakriteria: perusahaan mempubli-kasikan laporan keuangan secara berturut-turut selama tahan 2015 sampai dengan tahun 2018, perusahaan memiliki data mengenai kepemilikan saham manajerial. Pengambilan sampel yang telah ditetapkan, maka diperoleh sampel akhir sebanyak 6 perusahaan dengan 4 periode, maka didapat 24 data. Sampel yang dijadikan obyek penelitian perusahaan tambang dari tahun 2015 sampai dengan tahun 2018, antara lain: PT. Adaro Energy Tbk (ADRO), PT Atlas Resources Tbk (ARII), PT Bayan Resources Tbk (BYAN), PT Citatah Tbk (CTTH), PT Surya Esa Perkasa (ESSA), dan PT Indika Energi (INDY) Tbk.

Jenis Data yang digunakan adalah data sekunder yaitu penggunaan data yang berasal dari dokumen-dokumen yang sudah ada. Untuk menguji apakah ROA berpengaruh terhadap nilai perusahaan, dan menguji apakah pengungkapan kepemilikan mana-jerial mempunyai pengaruh terhadap hubungan antara ROA dengan nilai perusahaan, maka pengujian dalam penelitian ini dapat dilakukan sebagai berikut:

1. Pengujian parsial (Uji-t), Pengujian ini dilakukan untuk mengetahui variabel bebas (kinerja keuangan) secara parsial berpengaruh signifikan terhadap variabel moderasi (Good Corporate Governance) dan untuk mengetahui variabel bebas dan variabel 
moderating secara parsial mempunyai penga-ruh yang signifikan terhadap variabel terikat (nilai perusahaan).

2. Uji ketepatan model (Uji F), menunjukkan apa-kah persamaan regresi yang terbentuk memiliki ketepatan model (gooness of fit) yang tinggi.

\section{HASIL DAN PEMBAHASAN}

\section{Hasil Penelitian}

1. Nilai Perusahaan

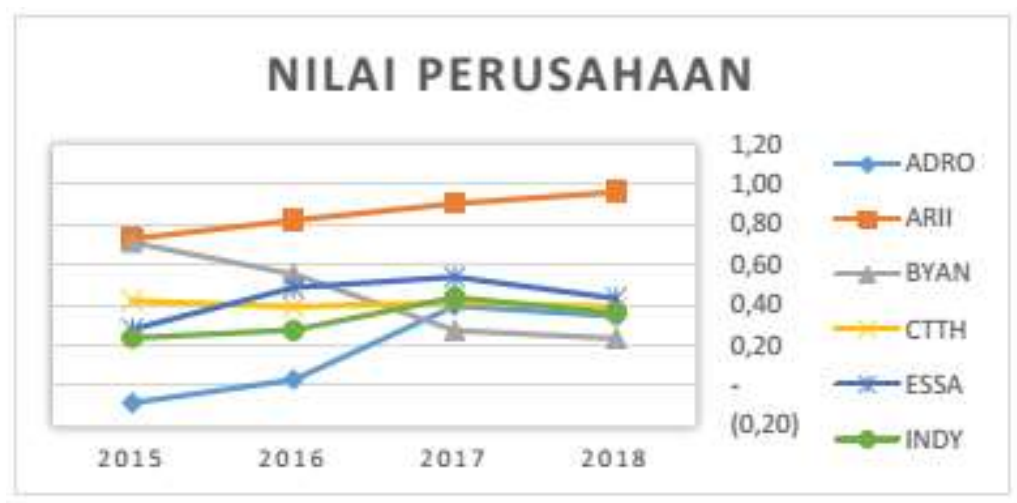

Sumber : Pengolahan Data

Gambar 2.

Kurva Nilai Perusahaan Pada Perusahaan Tambang Tahun 2015 - 2018

Berdasarkan grafik nilai perusahaan, dapat dilihat bahwa ARII memiliki nilai perusahaan yang cenderung berbeda dengan kelima perusahaan lain (ADRO, BYAN, CTTH, ESSA, dan INDY). Dan kondisi tersebut cenderung memiliki kenaikan disetiap tahunnya. Untuk perusahaan yang memiliki nilai terendah adalah BYAN, meskipun di 2015 menjadi peringkat ke -2 .

2. Return On Assets

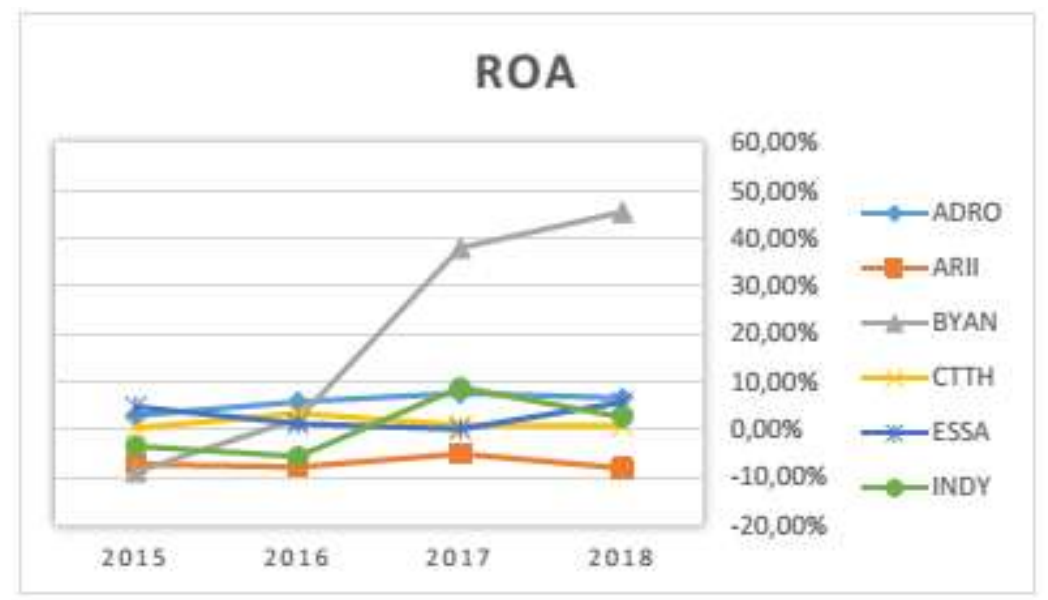

Sumber : Pengolahan Data

\section{Gambar 3.}

Kurva Return On Assets Pada Perusahaan Tambang Tahun 2015 - 2018

Berdasarkan kurva Return On Assets, dapat dilihat bahwa BYAN memiliki Return On Assets yang cenderung berbeda dengan kelima perusahaan lainnya (ADRO, BYAN, 
CTTH, ESSA, dan INDY). Dan ARII yang pada nilai perusahaannya berada diposisi tertinggi, namun memiliki ROA yang paling rendah.

3. Good Corporate Governance

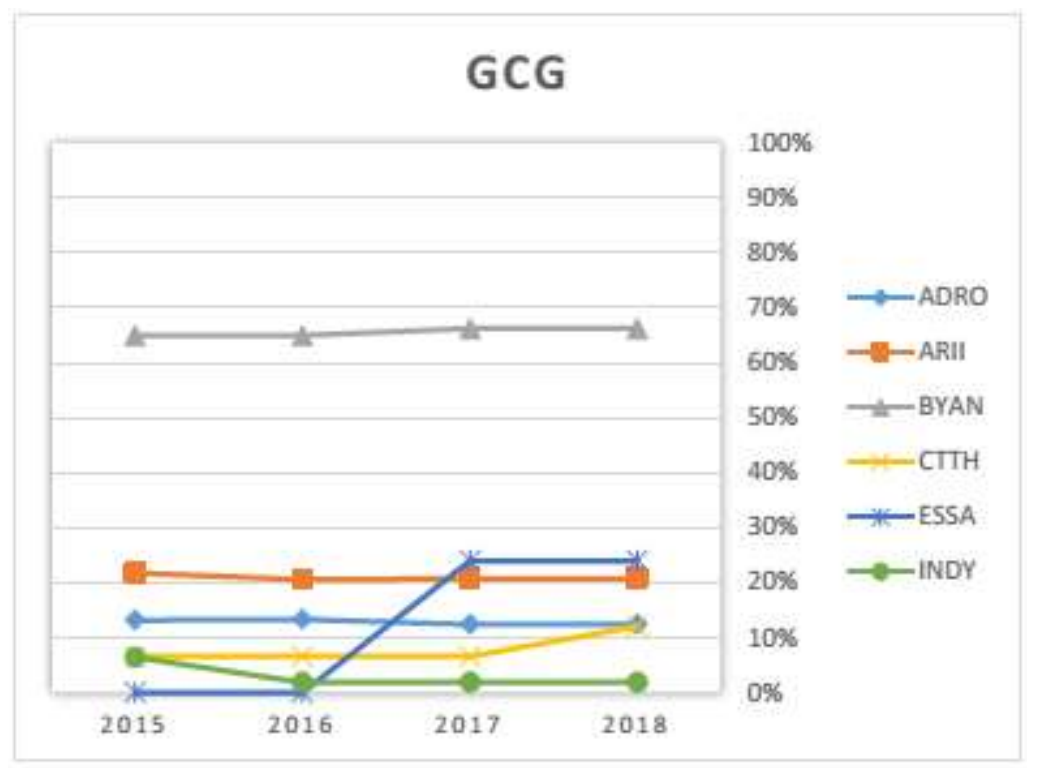

Sumber : Pengolahan Data

Gambar 4.

Kurva Good Corporate Governance Pada Perusahaan Tambang Tahun 2015 - 2018

Berdasarkan kurva Good Corporate Governance, nampak bahwa BYAN. memiliki $G C G$ yang cenderung berbeda dengan ketiga perusahaan lainnya (ADRO, BYAN, CTTH, ESSA, dan INDY). Terbukti BYAN memiliki Good Corporate Governance terbesar dari tahun 2015 sampai dengan 2018, kecuali tahun 2008 cenderung memiliki Good Corporate Governance menurun.

Pembahasan

Tabel 1.

Hasil Pengaruh Kinerja Keuangan (X1), Good Corporate Governance (X2) dan Interaksi (X1.X2) Terhadap Nilai Perusahaan (Y)

\begin{tabular}{ccccc}
\hline Model & Nilai & Sign & Arah & Pengaruh \\
\hline $\mathrm{X} 1$ & -2.75147 & 0.0000 & - & Tidak \\
$\mathrm{X} 2$ & 0.42482 & 0.1618 & + & Pengaruh \\
$\mathrm{X} 1 \mathrm{X} 2$ & 2.53233 & 0.0000 & + & Pengaruh \\
\hline
\end{tabular}

Keterangan:

$\mathrm{Y} \quad=$ Nilai Perusahaan

$\mathrm{X} 1 \quad=$ KinerjaKeuangan

$X 2=$ Good Corporate Governance

$\mathrm{X} 1 \mathrm{X} 2=$ Interaksi Kinerja Keuangan dan Good Corporate Governance

Persamaan Regresi yang dihasilkan adalah sebagai berikut :

$$
Y=0,46218-2,75147 X_{1}+0,42482 X_{2}+2,53233 X_{1} X_{2}
$$


Hasil Uji t dapat dijelaskan sebagai berikut:

Nilai koefisien regresi X1 sebesar -2,75147 dengan tingkat signifikansi sebesar 0,0000 kurang dari 5\% (sign < 5\%). Maka H0 ditolak dan H1 diterima yang berarti kinerja keuangan (X1) secara parsial berpengaruh signifikan terhadap nilai perusahaan (Y). Nilai koefisien regresi bertanda negative, yang artinya berpengaruh signifikan negative terhadap nilai perusahaan tambang yang terdaftar di Bursa Efek Indonesia.

Nilai koefisien regresi X2 0,42482 dengan tingkat signifikansi sebesar 0,1618 lebih dari 5\% (sign > 5\%). Maka H0 diterima dan H1 ditolak yang berarti Good Corporate Governance (X2) secara parsial tidak berpengaruh signifikan terhadap nilai perusahaan (Y). Nilai koefisien regresi pada variabel Good Corporate Governance bertanda positif, yang artinya Good Corporate Governance berpengaruh positif namun tidak signifikan terhadap nilai perusahaan, sehingga hipotesis ke-1 "Diduga bahwa Good Corporate Governance mempunyai pengaruh positif terhadap nilai perusahaan tambang yang terdaftar di Bursa Efek Indonesia", teruji kebenarannya.

Nilai Koefisien regresi interaksi antara kinerja keuangan dan Good Corporate Governance (X1X2) terhadap nilai perusahaan sebesar 2,53233 dengan tingkat signifikan sebesar 0,13067 kurang dari 5\% (sign < 5\%). Maka H0 ditolak dan H1 diterima yang berarti interaksi antara kinerja keuangan (X1) dan Good Corporate Governance (X2) secara parsial berpengaruh signifikan terhadap nilai perusahaan (Y). Nilai koefisien regresi antara kinerja keuangan dan Good Corporate Governance (X1X2) bertanda positif, yang artinya interaksi kinerja keuangan dan Good Corporate Governance berpengaruh positif signifikan, sehingga hipotesis kedua "Diduga bahwa Good Corporate Governance mampu memoderasi pengaruh kinerja keuangan terhadap nilai perusahaan tambang yang terdaftar di Bursa Efek Indonesia”, teruji kebenarannya, karena Good Corporate Governance memberikan kontribusi pengaruh kinerja keuangan terhadap nilai perusahaan.

1. Uji Ketepatan Model (Uji F)

Tabel 2.

Hasil Uji F

\begin{tabular}{ccc}
\hline F & Signifikasi & R2 \\
\hline 5.33515 & 0.00727 & 0.44453 \\
\hline
\end{tabular}

Berdasarkan tabel Uji $\mathrm{F}$ terlihat bahwa nilai $\mathrm{F}$ hitung yang dihasilkan sebesar 5,33515 dengan tingkat signifikan sebesar 0,00727 kurang dari 5\% (sig < 5\%) maka H0 ditolak dan $\mathrm{H} 1$ diterima yang berarti model persamaan regresi yang terbentuk memiliki goodness of fit atau ketepatan model yang tinggi.

\section{Koefisien Determinasi (R2)}

Besarnya pengaruh kinerja keuangan (X1), Good Corporate Governance (X2) dan interaksi antara kinerja keuangan dan Good Corporate Governance (X1X2) terhadap nilai perusahaan (Y) dapat dilihat dari nilai R2 yaitu sebesar 0,44453 yang berarti variabel kinerja keuangan (X1), Good Corporate Governance (X2) dan interaksi antara kinerja keuangan dan Good Corporate Governance (X1X2) mampu mempengaruhi nilai perusahaan (Y) sebesar 44,45\% dan sisanya 55,55\% dijelaskan oleh variabel lain di luar model. 
3. Pengaruh Kinerja Perusahaan Terhadap Nilai Perusahaan

Dari hasil pengujian hipotesis yang telah dilakukan diketahui bahwa secara parsial kinerja keuangan berpengaruh signifikan negative terhadap perusahaan. Hal ini menunjukkan bahwa semakin naik kinerja dari perusahaan tidak akan mempengaruhi nilai perusahaan, namun belum teruji sepenuhnya.

Dari hasil penelitian menunjukkan para investor tidak melakukan overview suatu perusahaan dengan melihat rasio keuangan sebagai alat evaluasi investasi. Namun hal ini belum sepenuhnya teruji kebenarannya karena memiliki koefisien regresi negative. Bisa saja investor memakai indicator lain dalam mengukur kinerja keuangan, karena dalam mengukur kinerja masih ada perhitungan ROE (Return of Equity).

Penelitian ini pun mendukung penelitian dari Tjandrakirana (2012) yang menyatakan bahwa ROA tidak berpengaruh terhadap nilai perusahaan. Hal ini dilihat dari uji t yang telah dilakukan, yang menunjukkan bahwa variabel bebas yaitu ROA memiliki nilai Sig. 0.354 yang mana lebih besar dari 0,05. Lain halnya dengan ROE yang memiliki nilai Sig. 0,005 yaitu kurang dari atau lebih kecil dari 0,05. Hal ini menandakan bahwa hanya variabel bebas yaitu ROE yang berpengaruh terhadap nilai perusahaan di BEI.

Selain itu hal yang diperlukan dalam penelitian ini adalah keakurata dari sebuah data, seluruh laporan keuangan yang akan diolah oleh peneliti harus diaudit oleh Akuntan Publik yang terpercaya. Supaya tidak terjadi fraud seperti dalam Wimar dan Ali (2018), yang mengangkat isu Etika dalam Management Keuangan, yang menjabarkan beberap kasus penyalah gunaan laporan keuangan untuk tujuan tertentu. Sehingga untuk peniliti berikutnya, wajib mewaspadai data laporan keuangan yang akan diolah.

Berdasarkan hasil penelitian, maka dapat disimpulkan bahwa ketika tingkat laba dalam kinerja keuangan yang dicapai perusahaan semakin membaik maka tidak akan memiliki pengaruh yang signifikan pada nilai perusahaan. Sehingga ROA bukan faktor yang dapat sepenuhnya mempengaruhi nilai perusahaan.

\section{Good Corporate Governance sebagai Variabel Pemoderasi}

Dari hasil pengujian hipotesis yang telah dilakukan dapat diketahui bahwa secara parsial interaksi antara kinerja keuangan dan Good Corporate Governance berpengaruh signifikan terhadap nilai perusahaan. Hal ini menunjukkan bahwa variabel Good Corporate Governance yang diproksikan dengan kepemilikan manajerial adalah variabel yang memoderasi pengaruh kinerja keuangan terhadap nilai perusahaan.

Hasil ini sesuai dengan hipotesis yang diajukan yaitu Good Corporate Governance mampu memoderasi pengaruh kinerja keuangan terhadap nilai perusahaan tambang yang terdaftar di Bursa Efek Indonesia, terbukti kebenarannya.

Hal ini mungkin disebabkan oleh adanya harapan dari para investor terhadap adanya kepemilikian manajerial yang dapat membawa dampak positif terhadap harga saham di pasar. Dampak positif dapat berarti meningkatkan kinerja keuangan perusahaan sehingga pada periode tertentu harga pasar dari perusahaan yang memiliki kepemilikan manajerial tinggi lebih stabil dibandingkan dengan kepemilikan manajerial yang rendah, khususnya pada perusahaan tambang yang terdaftar di Bursa Efek Indonesia. 
Penelitian pun mendukung Octavia (2017), yang menyatakan bahwa Kepemilikan Manajerial dapat digunakan untuk memprediksi Nilai Perusahaan pada perusahaan manufaktur yang terdaftar di BEI.

\section{KESIMPULAN}

Berdasarkan hasil analisis regresi linear berganda, maka kesimpulan yang diperoleh adalah 1) Kinerja Keuangan yang hanya diukur menggunakan ROA tidak mampu meningkatkan nilai perusahaan tambang yang terdaftar di Bursa Efek Indonesia. Hal ini menunjukkan bahwa semakin tinggi kinerja keuangan tidak akan berpengaruh terhadap kinerja keuangan. Karena masih banyak faktor lain yang menjadi tolak ukur dari kinerja keuangan. 2) Good Corporate Governance mampu memoderasi pengaruh kinerja keungan terhadap nilai perusahaan tambang yang terdaftar di Bursa Efek Indonesia. Hal ini menunjukkan bahwa semakin tinggi kepemilikan manajerial maka semakin baik nilai perusahaan tersebut. Terbukti apabila terdapat perubahan struktur kepemilikan sebuah perusahaan akan membuat investor semakin tertarik pada perusahaan tersebut dan meningkatkan permintaan atas saham tersebut lalu membuat harga saham perusahaan semakin naik. Hal juga mengindikasikan kepercayaan dari para investor kepada para Dewan Komisaris dan Direktur dalam mengelola perusahaan tambang ini. Bagi penelitian selanjutnya, peneliti hendaknya menambah jumlah sampel penelitian dan juga me-libatkan sektor industri yang lain agar mencerminka reaksi dari pasar modal secara keseluruhan. Penelitian selanjutnya dapat menggunakan proksi kinerja ke-uangan dan proksi GCG yang lain, misalnya Price Book Value, leverage, Komisaris Independen, Komite Audit atau kriteria lain yang telah ditetapkan.

\section{DAFTAR RUJUKAN}

Amri, S., Haryono, A. T., \& Warso, M. M. (2016). Pengaruh Good Corporate Governance terhadap Kinerja Karyawan PT Aditec Cakrawiyasa Semarang. Journal of Management, 02 (2).

Agrayana, Sudjana, \& Sulasmiyati. (2017). Penggunaan Rasio Keuangan untuk mengukur kinerja keuangan perusahaan. Jurnal Administrasi Bisnis.

Astuti, A., Rahman, A. \& Sudarno, S. (2015). Pengaruh kepemilikan keluarga terhadap kinerja perusahaan dengan agency cost sebagai variable moderating. Jurnal Dinamika Akuntansi, 7(2), 98-108.

Bastian, I. (2001). Akuntansi Sektor Publik. Yogyakarta: Universitas Gajah Mada.

Brigham, E.F. \& Gapenski, L.C. 1996. Intermediate Financial Management. Fifth Edition. Orlando: The Dryden Press.

Dinar, Trikartika, \& Iradianty. (2017). Pengaruh Good Corporate Governance Terhadap Nilai Perusahaan. e-Proceeding of Management.

El-Chaarani, H. (2014). The Impact of Corporate Governance on the Performance of Lebanese Banks. The International Journal of Business and Finance Research, 8(5), 22-34.

Husnan, S. 2000. Manajemen Keuangan Teori dan Penerapan. Yogyakarta: BPFE.

Midiastuti, Puspa, P. \& Machfoedz, M. 2003. Analisis Hubungan Mekanisme Corporate Governance dan Indikasi Manajmen Laba. Makalah ini di-sajikan dalam: Simposium Nasional Akuntansi VI, Surabaya.

Munawir, 2001. Akuntansi Keuangan dan Manajmen, Edisi Pertama, BPFE, Yogyakarta.

Octavia. 2017. Pengaruh Kepemilikan Manajerial, dan Kepemilikan Insititusional Terhadap Nilai Perusahaan. Artikel Ilmiah Perbanas. 
OECD. (2004). The OECD Principles of Corporate Governance. France: Organization for Economic Co-operation and Development (OECD) Publications Service.

Pertiwi. (2012). Pengaruh Good Corporate Governance Terhadap Kinerja Keuangan. Jurnal Manajemen dan Kewirausahaan.

Sujoko. (2009). Good Corporate Governance dan Kebijakan Keuangan Perusahaan. Untag Press.

Tertius \& Christiawan. (2015). Pengaruh Good Corporate Governance terhadap Kinerja Perusahaan pada Sektor Keuangan. Business Accounting Review.

Tjandrakirana (2012). Pengaruh Kinerja Keuangan Terhadap Nilai Perusahaan Pada Perusahaan Manufaktur Yang Terdaftar Di Bursa Efek Indonesia

Villalonga, B. \& Amit, R. (2006). How do family ownership, control and management affect firm value?. Journal of Financial Economics, 80(2), 385-417.

Wimar dan Ali (2018). Ethical Issues In Financial Management. Contoh Kasus Penyalah Gunaan Laporan Keuangan untuk tujuan tertentu. 